\title{
Age-Related Differences in Animacy Effects as a Function of Word-Order Canonicity in a Verb-Final Language: Evidence from ERP
}

\author{
Se Jin Oh, Jee Eun Sung, Hyun Sub Sim \\ Department of Communication Disorders, Ewha Womans University, Seoul, Korea
}

Correspondence: Jee Eun Sung, PhD Department of Communication Disorders, Ewha Womans University, 52 Ewhayeodae-gil, Seodaemun-gu, Seoul 03760, Korea

Tel: $+82-2-3277-2208$

Fax: +82-2-3277-2122

E-mail: jeesung@ewha.ac.kr

Received: October 5, 2016

Revised: November 24, 2016

Accepted: November 29, 2016

This work was supported by the Ministry of Education of the Republic of Korea and the National Research Foundation of Korea (NRF2016S1A5B6913884)

\begin{abstract}
Objectives: Animacy is an important issue in the research of sentence processing, associated with thematic role assignment, grammatical relations and linear ordering of sentential constituents. Based on the animacy effects reported in previous research, the current study aimed to investigate whether the animacy effects are replicated in processing Korean sentences in which canonicity is manipulated in younger and elderly adults, using event-related potentials (ERPs). Methods: The ERP data from 34 adults (16 young and 18 elderly) were analyzed. Simple transitive sentences composed of 2 noun phrases, an adverb, and a verb were used as experimental stimuli and animacy was manipulated at the grammatical object position in canonical and non-canonical sentences. ERPs were recorded while the participants performed a sentence comprehension task. Results: For young adults, animate objects (NP2) in canonical sentences engendered greater N400 effects than inanimate objects, whereas inanimate objects (NP1) in non-canonical sentences induced greater $\mathrm{N} 400$ effects than animate objects. In the elderly group, there were no significant animacy effects for any of the critical words. Conclusion: The current study demonstrated that animacy effects on sentence processing are closely related to the linear ordering of arguments based on animacy hierarchy, and when these semantic expectancies are violated, processing costs could be raised. However, it seems that this animacy processing might be less efficient in the aging population.
\end{abstract}

Keywords: ERP, N400, Animacy, Canonicity, Aging, Sentence processing
Sentence comprehension occurs successfully when the meanings of individual words are not only retrieved but are connected with proper thematic roles. In the process of assigning thematic roles, the human brain integrates semantic information from individual words with syntactic or morpho-syntactic information such as word order or case markers (de Swart, Lamers, \& Lestrade, 2008). In the research of semantic-syntactic interplay, animacy is an important issue that has received great attention. Considered as a semantic concept which pervasively or universally exists in the grammar of languages, animacy has been investigated in connection with other semantic or syntactic information of languages (Dahl \& Fraurud, 1996).
A substantial body of literature has revealed that animacy is associated with thematic role assignment, grammatical relations (e.g., subject, object) and linear ordering of sentential constituents. The studies have suggested that animate nouns are prototypically assigned the agent role whereas inanimate nouns are more likely assigned the patient role (Bock \& Warren, 1985; Folli \& Harley, 2008; van Valin \& LaPolla, 1997). It has also been reported that animate nouns are preferred for the grammatical subject while inanimate nouns for the object (Bock \& Warren, 1985; Folli \& Harley, 2008; Givón, 1979). This inclination appears even when additional processing for syntactic transformation is required as in passive sentences with an inanimate agent (e.g., The man was hit 
by a car.). The animate subject preference appears more strongly in certain languages such as Korean (Palmer, 1994; Yeon, 2015), Japanese (Kuno, 1973), Navajo (Hale, 1973), and Mayan (Minkoff, 2000) where inanimate nouns are restricted or even prohibited in the subject position of transitive sentences. The research of animacy effects has also revealed that animacy information has an impact on the arrangement of sentential constituents. According to the studies, there is a preference for organizing constituents based on animacy hierarchy (human $>$ (other) animate $>$ inanimate $>a b$ stract) (Comrie, 1989). It has been reported that animate nouns precede inanimate nouns in several types of sentential structures such as transitive sentences (Kempen \& Harbusch, 2004), ditransitive sentences (Paczynski \& Kuperberg, 2011) and possessive phrases (Rosenbach, 2005).

Regarding the animacy-related phenomenon, several researchers suggest that the animate subject preference might be attributed to the properties of animate entities, such as a faster activation rate than inanimate ones (Bock \& Warren, 1985; McDonald, Bock, \& Kelly, 1993) and frequent semantic access (Bock, Loebell, \& Morey, 1992). According to this perspective, animate nouns are placed at a more prominent position since they are more accessible or salient than inanimate ones. Bornkessel and Schlesewsky (2006) depicted animacy as the information used for assigning the hierarchical positions of sentential constituents, along with such information as thematic roles, case markers, and grammatical positions. They proposed that due to their higher rank, animate nouns are considered more prominent and assigned the thematic role of actor (Lamers \& de Swart, 2012). They also suggested that when the two arguments in a transitive sentence are not maximally distinct in prominence hierarchy, additional processing costs arise (BornkesselSchlesewsky \& Schlesewsky, 2009).

The attempts to find evidence of animacy effects on sentence processing have been made in the research of online sentence processing, which demonstrates more intact language processing compared to off-line measures (Burke \& MacKay, 1997; Tyler, 1985). In particular, event-related potential (ERP) studies have suggested neurophysiological correlates of animacy processing, such as the N400 and P600. While the P600 effect has been reported in some studies addressing the processing of implausible or syntactically violated sentences, the N400 effect, an ERP component associated with semantic processing, has been primarily reported in connection with less preferred animacy processing, thematic role assignment or linear ordering of arguments (Frisch \& Schlesewsky, 2001; Li, Zhao, Zheng, \& Yang, 2015; Nakano, Saron, \& Swaab, 2010; Paczynski \& Kuperberg, 2011; Weckerly \& Kutas, 1999). The N400 is a negative-going deflection around $250-600 \mathrm{~ms}$ after the onset of critical stimuli (Weckerly \& Kutas, 1999). It is seen in response to semantic incongruities or violations of semantic expectancies (Kutas \& Hillyard, 1980; Luck, 2014), difficulties in integrating a word into preceding context (Weckerly \& Kutas, 1999), or less preferred thematic role processing, often associated with animacy information (Paczynski \& Kuperberg, 2011).

A couple of studies investigated animacy effects for sentenceinitial nouns with the role of grammatical subject. Weckerly and Kutas (1999) revealed that greater N400 effects were elicited only for the inanimate nouns at the subject position both in main clauses and in object relative clauses in English. The researchers interpreted the results as the reflection of unexpectedness of encountering inanimate nouns at the sentence-initial position. Li et al. (2015) showed that animacy information caused additional difficulties in the processing of Chinese sentences. They found that larger N400 effects were elicited from the verb following a subject noun with the patient role only when inanimate but not animate. Although all the patient-first sentences had the passive voice structure when additional processing costs are known to be required, only inanimate patient nouns at the subject position engendered significant N400 effects. The researchers speculated that these additional costs would be the results from the nature of inanimate entities such as less salience or less lexical-semantic accessibility. The effects of animacy have been also reported on the second noun phrase at the object position. Paczynski and Kuperberg (2011) examined animacy effects of nouns at the object position in English plausible transitive sentences with an animate subject. The researchers reported that animate objects engendered larger N400 effects compared to inanimate ones, demonstrating that animate nouns are less preferred at the object position. They suggested that these results could be explained by animacy effects associated with the configuration of sentence constituents based on animacy hierarchy rather than the accessibility/salience hypothesis that animate entities are more accessible (Prat-Sala \& Branigan, 2000). Specifi- 
cally, since animate nouns tend to be placed at earlier syntactic positions based on animacy hierarchy, animate nouns at the object position could evoke additional processing costs. Frisch and Schlesewsky (2001) demonstrated additional processing costs for the arguments with identical animacy information (animate-animate) compared to those with distinct animacy configuration (animateinanimate) in ungrammatical German sentences with double subjects. They found that the increased N400 activation followed by the P600 was only observed for the second nouns in the condition of animate-animate, indicating the possibility that animacy performs a role to resolve the thematic conflicts caused by the identical grammatical roles.

When the aforementioned studies are taken together, it is clear that animacy obviously exerts its influence on sentence processing. Especially, processing costs derived from animacy processing seems to be strongly related to the preference for linear ordering based on animacy hierarchy (animate > inanimate). If animate nouns which are more likely placed at earlier syntactic positions are placed at later positions such as the object position, additional processing costs seem to be engendered. Likewise, inanimate nouns at the sentence initial position are expected to be processed with additional processing costs. However, the diverse results from dissimilar structures in different languages give rise to the necessity for further research on different languages to reveal how animacy affects sentence processing depending on linear ordering of noun arguments with a clear picture of the universal and language-specific animacy effects on sentence processing.

Korean is one of the ideal languages to investigate animacy effects, given its sophisticated case marking system and flexible word order. It follows a canonical word order of Subject-Object-Verb but the sentential constituents can be scrambled rather freely as long as the predicates are retained at the sentence final position (Chang, 1996; Müller-Gotama, 1994). A relatively free word order in Korean is allowed with a rich case marking system since the case markers denote the thematic roles of each noun phrase rather than word order. Thus, unlike the languages in which thematic roles are assigned by word order, in Korean it is possible to examine animacy effects as a function of argument configuration by manipulating linear ordering of arguments without changing any meaning or thematic roles. Concerning animacy effects, Korean is known to be sensitive to animacy information. The hierarchy of animacy plays more assertive roles in constructing sentence structures in Korean compared to other languages (Song, 1987; Yeon, 2015). For instance, the subject of transitive or passive sentences is mostly animate in Korean in contrast to English in which inanimate entities could be a subject in those structures (Palmer, 1994; Williamson \& Kim, 2013; Yeon, 2015). Specifically, higher animacy is more strictly placed at the higher position, such as the subject position, and therefore, inanimate subjects are restricted from co-occurring with animate objects in transitive sentences or passive sentences in Korean.

Meanwhile, the various sub-processes involved in language processing are known to be affected by cognitive aging during the process of normal aging. In general, researchers have accepted that language processing at the lexical-semantic level is relatively intact whereas that at the syntactic or discourse-level is impaired in the aging population (Federmeier, van Petten, Schwartz, \& Kutas, 2003; Wingfield, 2000). Concerning semantic processing in old age, a large number of studies have revealed the elderly population's fairly stable semantic memory or conceptual representations in tasks such as lexical decision or organization (Burke \& Peters, 1986; Howard, 1983; Scialfa \& Margolis, 1986). However, studies examining online processing, which could sensitively detect slowness or less activation, have suggested age-related differences demonstrating declined efficiency in semantic processing such as word recognition or lexical access in elderly adults (Balota \& Duchek, 1988; Bowles \& Poon, 1985). Concerning ERP research, decreased N400 components have been reported in the response of elderly adults performing lexical judgment tasks (Federmeier, McLennan, Ochoa, \& Kutas, 2002; Federmeier et al., 2003; Friederici, Hahne, \& Von Cramon, 1998; Hamberger, Friedman, Ritter, \& Rosen, 1995). The researchers interpreted the decrement in the N400 effect as the reflection of deteriorated facilitation of contextual cues or attenuated processing capacity in elderly adults (Federmeier et al., 2002; Hamberger et al., 1995).

Although the studies on lexical level revealed age-related differences in lexico-semantic processing, ERP studies disclosing age differences during sentence processing are limited. As a behavioral study, Altmann and Kemper (2006) investigated whether elderly adults showed the animate subject preference as much as young 
adults in a sentence production task. In the task, the participants were asked to produce a sentence with three visually-presented words (a verb, an animate noun, and an inanimate noun). The results revealed that regardless of verb types, which prefer either an animate subject or an inanimate subject, the animate subject preference appeared for both young and elderly adults even when passivization was required. However, the older group was found to be less sensitive to the animate subject preference than the young group. Compared to younger adults, they were more affected by the order of nouns presented as stimuli rather than animacy information. Based on these results, the researchers suggested that elderly adults could be less efficient in making use of animacy information during sentence processing. A couple of ERP studies have revealed the correlation between animacy processing and cognitive abilities during sentence processing, implying the possibility of age-related differences. Nakano et al. (2010) assessed the ERP patterns of animacy processing for individuals with high or low working memory span. ERPs were collected while the participants were listening to simple active sentences in which the plausibility of thematic relations between the subject noun and the verb was manipulated. The results showed that for the participants with high working memory span, larger anterior negative shift was engendered for inanimate nouns at the sentence-first position, as evidence of additional processing costs, but individuals with low span did not show such effects. Weckerly and Kutas (1999) examined the animacy effects in relation to reading comprehension ability. The electroencephalograms (EEGs) were analyzed for two grammatical subjects in both the main clause and following object relative clause with their animacy configuration manipulated into animate-inanimate and inanimate-animate. They found that for both high and low comprehenders, the N400 effect was observed with the inanimate noun at the subject positions of main clause. However, a greater N400 effect with the inanimate nouns than the animate ones at the subject position of object relative clauses was observed only for the high comprehenders, indicating the possibility that low comprehenders were less efficient in integrating animacy information into ongoing processing of constituents in embedded sentences. Given age-related decline in working memory and reading comprehension (Grady \& Craik, 2000; Stuart-Hamilton, 2000), age-related differences in animacy processing are expected to be observed.

The current study aimed to investigate whether animacy manipulation at the object position has any effects on processing Korean simple transitive sentences with canonical and non-canonical word order and how the animacy effects appears in elderly adults. We predicted that based on the preference for animacy hierarchy, in canonical sentences with subject-object order, animate objects would elicit larger N400 effects than inanimate objects and in noncanonical sentences with object-subject order, inanimate objects at the sentence initial position would engender greater N400 effects than animate objects. However, these effects would be attenuated in elderly groups given the possibility of reduced efficiency in integrating animacy information into ongoing sentence processing or lower sensitivity to animacy information in the aging population.

\section{METHODS}

\section{Participants}

A total of 40 Korean-speaking individuals participated in the study with 20 in a younger group and 20 in a normal elderly group. They were all native Korean speakers and right-handed with no history of neurological or psychiatric disorder based on a health screening questionnaire (Christensen, Multhaup, Nordstrom, \& Voss, 1991). Older adults were screened for cognitive and neuropsychological impairments based on the Korean version of MiniMental State Examination (K-MMSE; Kang, Jang, \& Na, 2012) and one older adult was excluded from the K-MMSE screening procedure (inclusion criteria $>16 \%$ ile). Four younger adults and one older adult were excluded due to excessive trial loss caused by artifacts (trial loss $>80 \%$ ). The data from 34 adults (16 young and 18 old) were entered into the data analysis. There was a significant difference in years of education between the two age groups $\left(F_{(1,32)}\right.$ $=36.998, p<.001)$. Descriptive information was provided in Table 1. Institutional Review Board (IRB) approval from the Ethics Com-

Table 1. Descriptive information on participants

\begin{tabular}{lcc}
\hline & Young group & Old group \\
\hline Gender (male:female) & $4: 12$ & $5: 13$ \\
Age (yr) & $28.12 \pm 5.57(23-40)$ & $65.50 \pm 2.43(61-72)$ \\
Education (yr) & $15.87 \pm 1.40(13-18)$ & $11.66 \pm 2.42(9-17)$ \\
\hline
\end{tabular}

Values are presented as number or mean $\pm \mathrm{SD}$ (range). 
mittee of Ewha Womans University was obtained for the present research (IRB No. 99-3). The data was collected from September 3, 2015 to September 30, 2015.

\section{Experimental materials and procedure}

One hundred fifty sentences (60 target sentences and 90 filler sentences) were used as experimental stimuli. Each sentence was composed of 4 phrases: a noun phrase 1 (NP1), an adverbial phrase (ADVP), a noun phrase 2 (NP2), and a verb. Animacy was manipulated only at the grammatical object position, resulting in the two different experimental conditions for canonical and non-canonical sentences: for canonical sentences, (1) animate subject+inanimate object and (2) animate subject+animate object; for non-canonical sentences, (1) inanimate object+animate subject and (2) animate object+animate subject. Each condition has 15 target sentences and critical words for analyses were NP2 for canonical sentences, and NP1 for non-canonical sentences. Appellations of human beings and names of objects were used for animate nouns and for inanimate nouns, respectively, in order to make the most typical sentence type (Lee, 2007). All nouns used as stimuli had a word frequency value higher than 100, which indicates high frequency words in Korean (Seo, 1998). One-way analysis of variance (ANO$\mathrm{VA})$ revealed that the difference in frequency between animate nouns and inanimate nouns used at the object position was not significant $\left(F_{(1,28)}=2.503, p>.05\right)$. Examples of stimuli were provided in Table 2.

As an offline task, a sentence comprehension task was administered to ensure that the participants were processing the stimuli. In a soundproof and electrically shielded room, the participants were asked to read a sequence of sentential phrases presented on the screen of a 24-inch LCD monitor and then choose the grammatical subject noun between the two nouns which were a subject and an object of the preceding sentence. In order to respond to the question, they had to press a keyboard button on the same side as the noun which they chose. Sentences were displayed in a wordby-word presentation manner using a Rapid Serial Visual Presentation (RSVP) paradigm (Figure 1) using E-Prime software (Psychology Software Tools, Pittsburgh, PA, USA). The duration of each displayed phrase was $700 \mathrm{~ms}$ with $200 \mathrm{~ms}$ inter-stimulus intervals and the last word (verb) was followed by the question "who?"
Table 2. Examples of stimuli for canonical and non-canonical sentences

\begin{tabular}{|c|c|}
\hline Condition & Example \\
\hline \multicolumn{2}{|l|}{ Canonical sentences } \\
\hline $\begin{array}{l}\text { Animate subject - Inani- } \\
\text { mate object }\end{array}$ & $\begin{array}{l}\text { Eonni-ka gabjagseureobgey Caegsang-ul mil-ta. } \\
\text { The sister-NOM abruptly The desk-ACC Push-DECL } \\
\text { The sister abruptly pushes the desk. }\end{array}$ \\
\hline $\begin{array}{l}\text { Animate subject - Animate } \\
\text { object }\end{array}$ & $\begin{array}{l}\text { Eonni-ka gabjagseureobgey Cinku-lul mil-ta. } \\
\text { The sister-NOM abruptly The friend-ACC Push-DECL } \\
\text { The sister abruptly pushes her friend. }\end{array}$ \\
\hline \multicolumn{2}{|l|}{ Non-canonical sentences } \\
\hline $\begin{array}{l}\text { Inanimate object - Ani- } \\
\text { mate subject }\end{array}$ & $\begin{array}{l}\text { Caegsang-ul gabjagseureobgey Eonni-ka mil-ta. } \\
\text { The desk-ACC abruptly The sister-NOM Push-DECL } \\
\text { The sister abruptly pushes the desk. }\end{array}$ \\
\hline $\begin{array}{l}\text { Animate object - Animate } \\
\text { subject }\end{array}$ & $\begin{array}{l}\text { Cinku-lul gabjagseureobgey Eonni-ka mil-ta. } \\
\text { The friend-ACC abruptly The sister-NOM Push-DECL } \\
\text { The sister abruptly pushes her friend. }\end{array}$ \\
\hline
\end{tabular}

$\mathrm{NOM}=$ nominative; $\mathrm{ACC}=$ accusative; $\mathrm{DECL}=$ declarative.

for $500 \mathrm{~ms}$ and then two choices for a maximum of 4,000 ms until the participants pressed a button. The inter-trial interval was 3,000 ms. The sentences were pseudo-randomized in order not to present sentences on the same condition consecutively.

\section{EEG recording and analysis}

EEG data was recorded via BrainVision BrainAmp Standard (Brain Products GmbH, Germany) with a 32-channel actiCAP embedded with $\mathrm{Ag} / \mathrm{AgCl}$ electrodes, following the International 10-20 system (Jasper, 1958). It was collected at a 500-Hz sampling rate with 0.1 to $100-\mathrm{Hz}$ band-pass filters. Left and right mastoids were used as the reference and the electrooculogram (EOG) was obtained from an electrode attached below the right eye to detect eye blinks. All impedances of electrodes were kept below $10 \mathrm{k} \Omega$.

EEG data was analyzed with EEGLAB software (Delorme \& Makeig, 2004) in MATLAB (http://www.mathworks.com). The data of critical words was epoched from $200 \mathrm{~ms}$ before the stimulus onset to $900 \mathrm{~ms}$ after the stimulus onset. The data was downsampled to $250 \mathrm{~Hz}$ and a 0.3 - to 3-Hz band-pass filter was applied. Artifacts were removed with ocular correction and other electronic activities over $\pm 50 \mu \mathrm{V}$ were excluded. After removing artifacts, ERP data was averaged and divided into the three midline electrodes $(\mathrm{Fz}, \mathrm{Cz}$, and $\mathrm{Pz})$ and four lateral regions: left anterior $(\mathrm{FP} 1$, F3, FC5, FC1, F7), left posterior (CP5, CP1, P7, P3, O1), right anterior (FP2, F4, FC2, FC6, F8), and right posterior (CP2, CP6, P4, P8, 


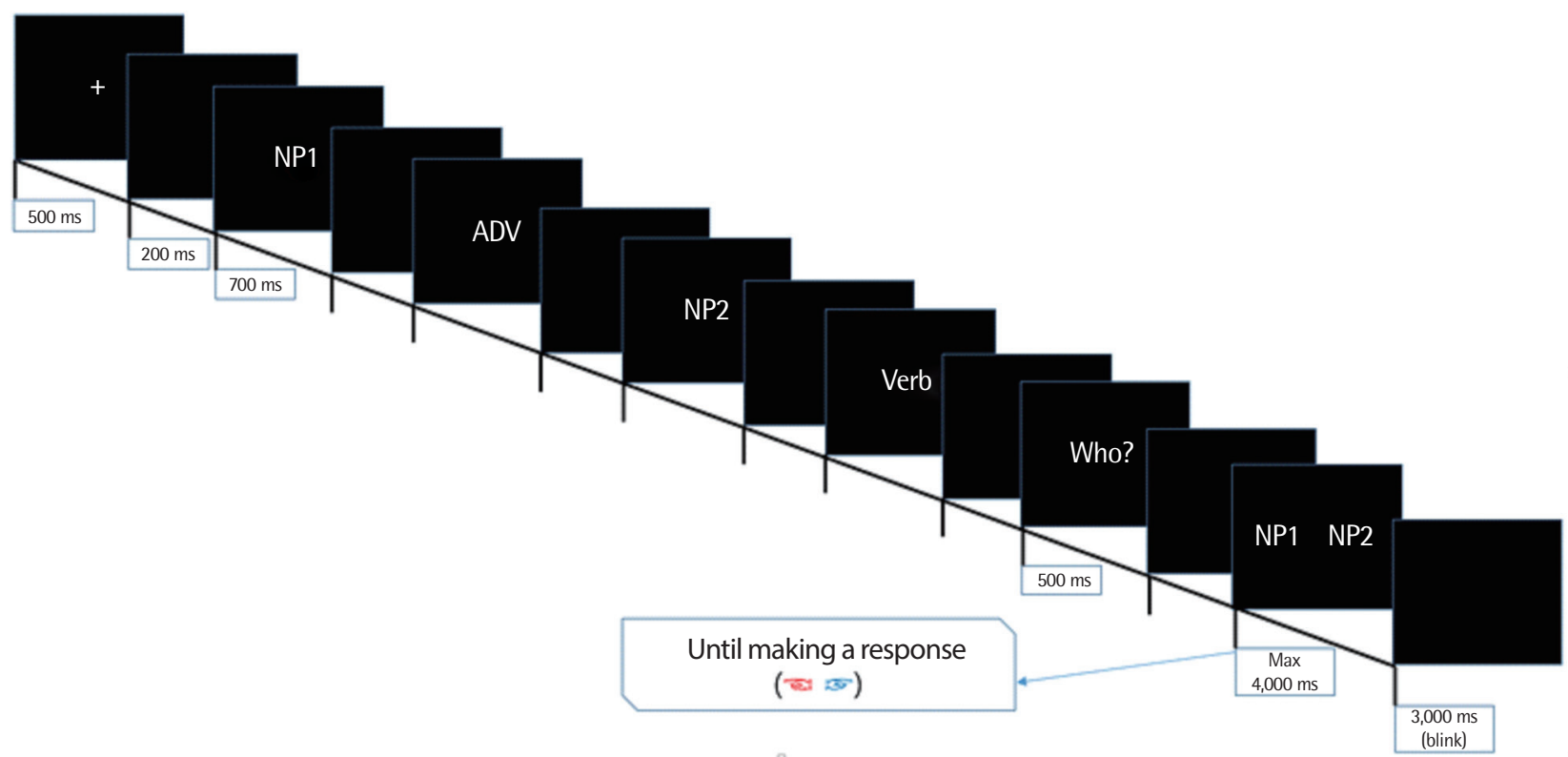

Figure 1. Rapid serial visual presentation paradigm.

O2) (Taler, Klepousniotou, \& Phillips, 2009; Wang, Schlesewsky, Philipp, \& Bornkessel-Schlesewsky, 2012). Four latency time windows (100-200 ms, 200-400 ms, 400-600 ms, 600-800 ms) were set based on visual inspection and previous research (Matzke, Mai, Nager, Rüsseler, \& Münte, 2002). The EEG data from correct responses was included for the analysis. For statistical analyses, ANOVAs were carried out separately for midline and lateral regions using SPSS ver. 22.0 (IBM, Armonk, NY, USA). We performed a 2 $\times 3$ two-way repeated ANOVA with animacy (animate vs. inanimate) and site (Fz, Cz, and $\mathrm{Pz})$ as within-subject factors for the midline analysis, and a $2 \times 2 \times 2$ three-way repeated ANOVA with animacy, laterality (left hemisphere vs. right hemisphere) and anteriority (anterior vs. posterior) for the lateral regions for each group in canonical and non-canonical sentences. Only significant main effects or interactions of animacy on the critical words were reported. In the case of violations of sphericity assumptions, the Greenhouse-Geisser correction was applied (Greenhouse \& Geisser, 1959).

\section{RESULTS}

\section{Behavioral data}

The responses to the sentence comprehension task were analyzed for mean accuracy rate and reaction time. The values of reaction time from correct responses within \pm 3 SD from the mean were included for the analysis. One-way repeated ANOVAs with animacy as a within-subject factor were conducted on accuracy and reaction time for each group. For accuracy, there were significant main effects for animacy both in canonical sentences $\left(F_{(1,17)}=8.588\right.$, $p<.01)$ and non-canonical sentences $\left(F_{(1,17)}=9.686, p<.01\right)$ only for elderly adults. No main effects for animacy were significant for young adults. For reaction time, main effects for animacy were significant both in canonical sentences $\left(F_{(1,17)}=5.517, p<.05\right)$ and non-canonical sentences $\left(F_{(1,17)}=10.480, p<.01\right)$ for elderly adults. For young adults, there was a significant main effect for animacy in non-canonical sentences $\left(F_{(1,15)}=5.669, p<.05\right)$. The descriptive data on mean accuracy rate and reaction time is displayed in Table 3.

\section{ERP data}

\section{Canonical sentences}

For younger adults, two-way repeated ANOVAs (animacy $\times$ site) for midline analysis revealed a significant two-way interaction between animacy and site $\left(F_{(2,32)}=4.252, p=.042\right)$ in the 100$200 \mathrm{~ms}$ time window. In post hoc comparisons, interaction contrasts using MMATRIX indicated that the animate object condition generated significantly greater negativity at central regions than the inanimate object condition $(p=.003)$. A marginally significant two-way interaction between animacy and site $\left(F_{(2,32)}=2.952\right.$, $p=.067)$ was obtained in the $200-400 \mathrm{~ms}$ time window, revealing 
Table 3. Descriptive data in canonical and non-canonical sentences for young and elderly adult group

\begin{tabular}{|c|c|c|c|c|}
\hline & \multicolumn{2}{|c|}{ Young group ( $N=16)$} & \multicolumn{2}{|c|}{ Old group ( $N=18$ ) } \\
\hline & Inanimate & Animate & Inanimate & Animate \\
\hline \multicolumn{5}{|l|}{ Accuracy (\%) } \\
\hline Canonical & $99.13 \pm .34$ & $99.60 \pm .25$ & $97.07 \pm 1.20$ & $89.27 \pm 1.94$ \\
\hline Non-canonical & $98.73 \pm .40$ & $98.73 \pm .40$ & $97.06 \pm .86$ & $81.47 \pm 3.30$ \\
\hline \multicolumn{5}{|l|}{ Reaction time (ms) } \\
\hline Canonical & $453.21 \pm 156.57$ & $455.05 \pm 163.44$ & $902.26 \pm 287.46$ & $1,035.97 \pm 334.91$ \\
\hline Non-canonical & $421.42 \pm 138.85$ & $473.09 \pm 171.75$ & $887.50 \pm 248.02$ & $1,115.35 \pm 441.10$ \\
\hline
\end{tabular}

Values are presented as number or mean \pm SD.

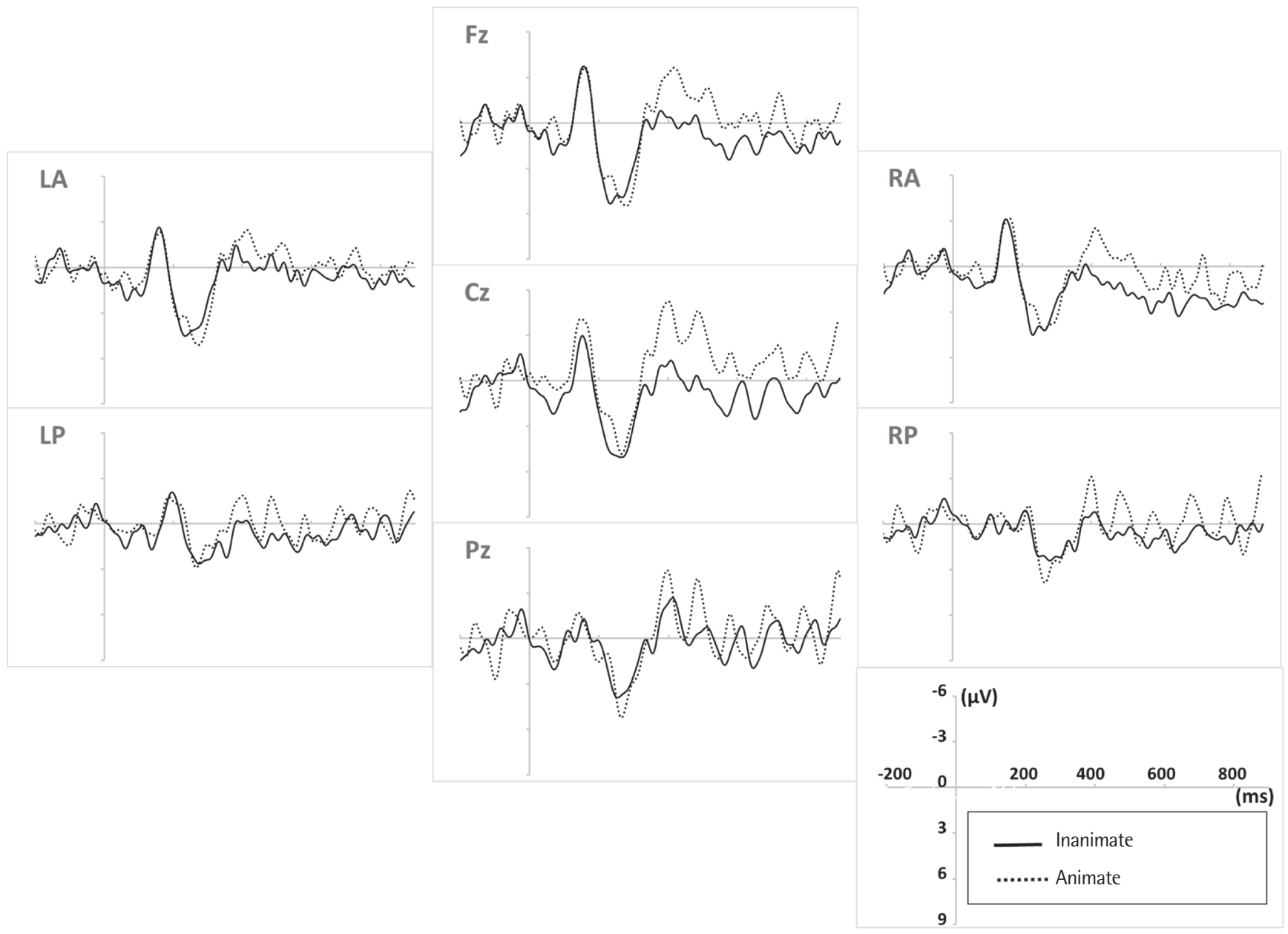

Figure 2. Grand-average waveforms for NP2 of canonical sentences for young adults. $L A=$ left anterior; $L P=$ left posterior; $R A=$ right anterior; $R P=$ right posterior.

greater negativity at central regions for animate objects than inanimate objects in post hoc comparisons $(p=.015)$. A main effect for animacy was significant in the 400-600 ms time window $\left(F_{(1,16)}=\right.$ $4.972, p=.040$ ) with larger negative shift to animate objects compared to inanimate objects. Three-way repeated ANOVAs (animacy $\times$ laterality $\times$ anteriority) for lateral regions revealed a sig- nificant three-way interaction among animacy, laterality and anteriority $\left(F_{(1,15)}=6.274, p=.024\right)$ in the $200-400 \mathrm{~ms}$ time window, induced by greater left-posterior negativity for animate objects than inanimate objects. A marginally significant three-way interaction among animacy, laterality and anteriority $\left(F_{(1,15)}=3.736\right.$, $p=.072)$ was obtained in the $400-600 \mathrm{~ms}$ time window, elicited by 


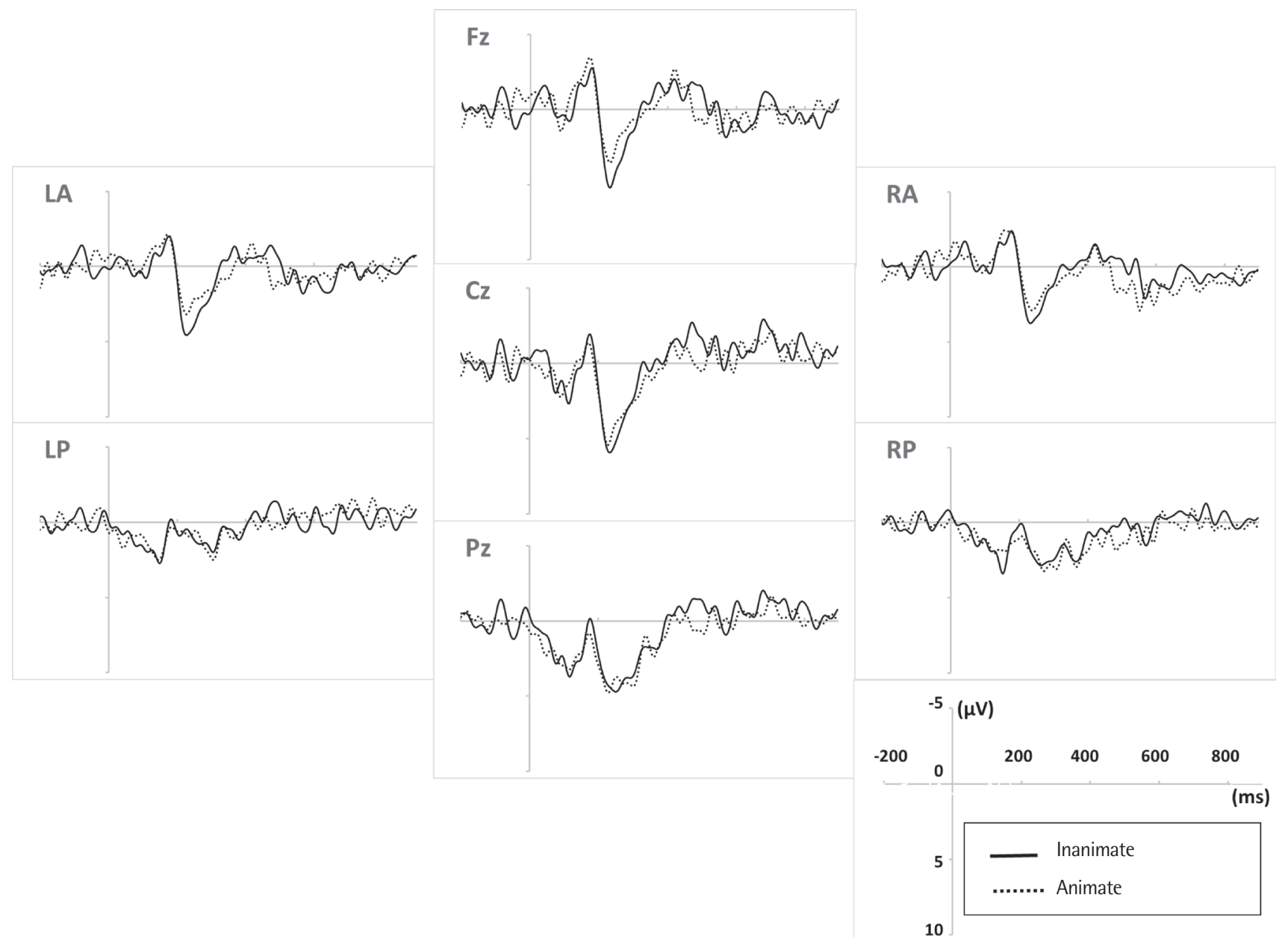

Figure 3. Grand-average waveforms for NP2 of canonical sentences for elderly adults. $L A=$ left anterior; $L P=$ left posterior; $R A=$ right anterior; $R P=$ right posterior.

Table 4. Results of ANOVAs for animacy effects in each time window

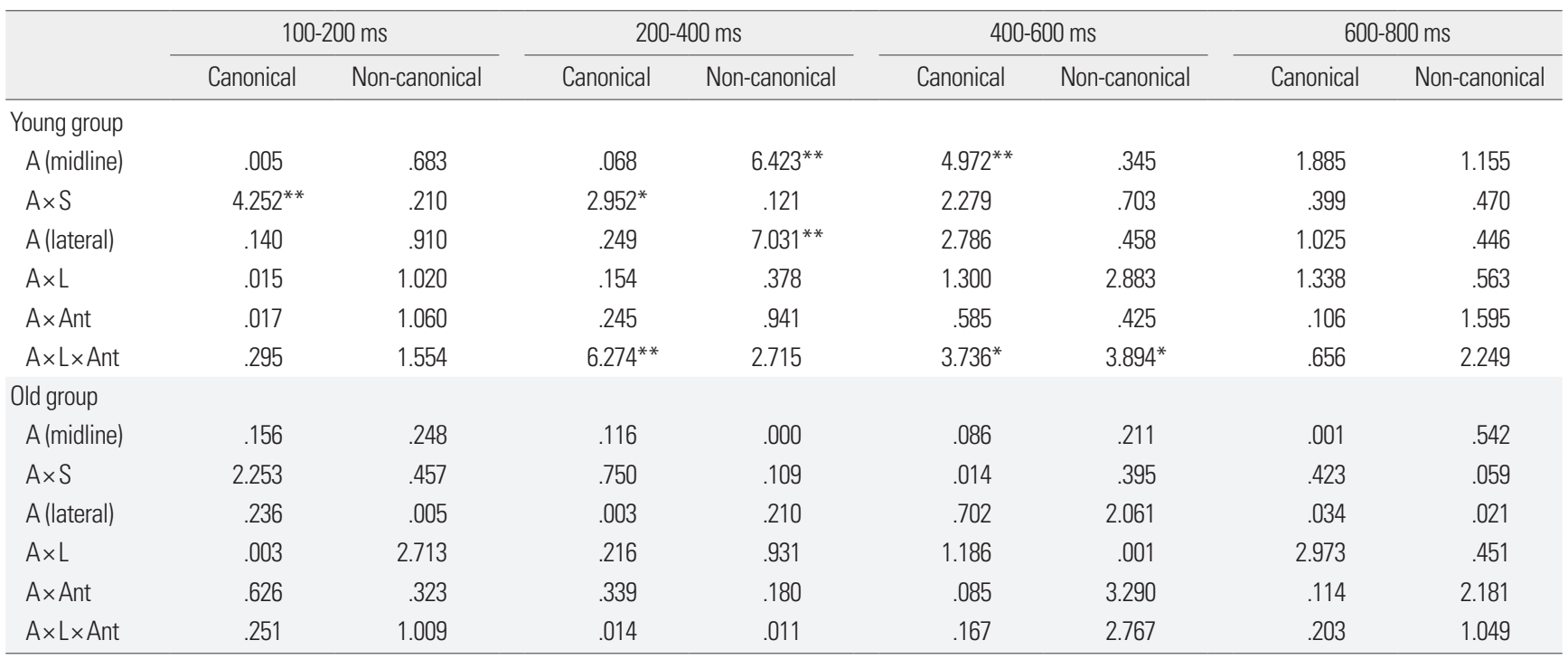

$A=$ animacy; $S=$ site; $L=$ laterality; Ant=anteriority. ${ }^{*} p<.08$, ${ }^{* *} p<.05$. 


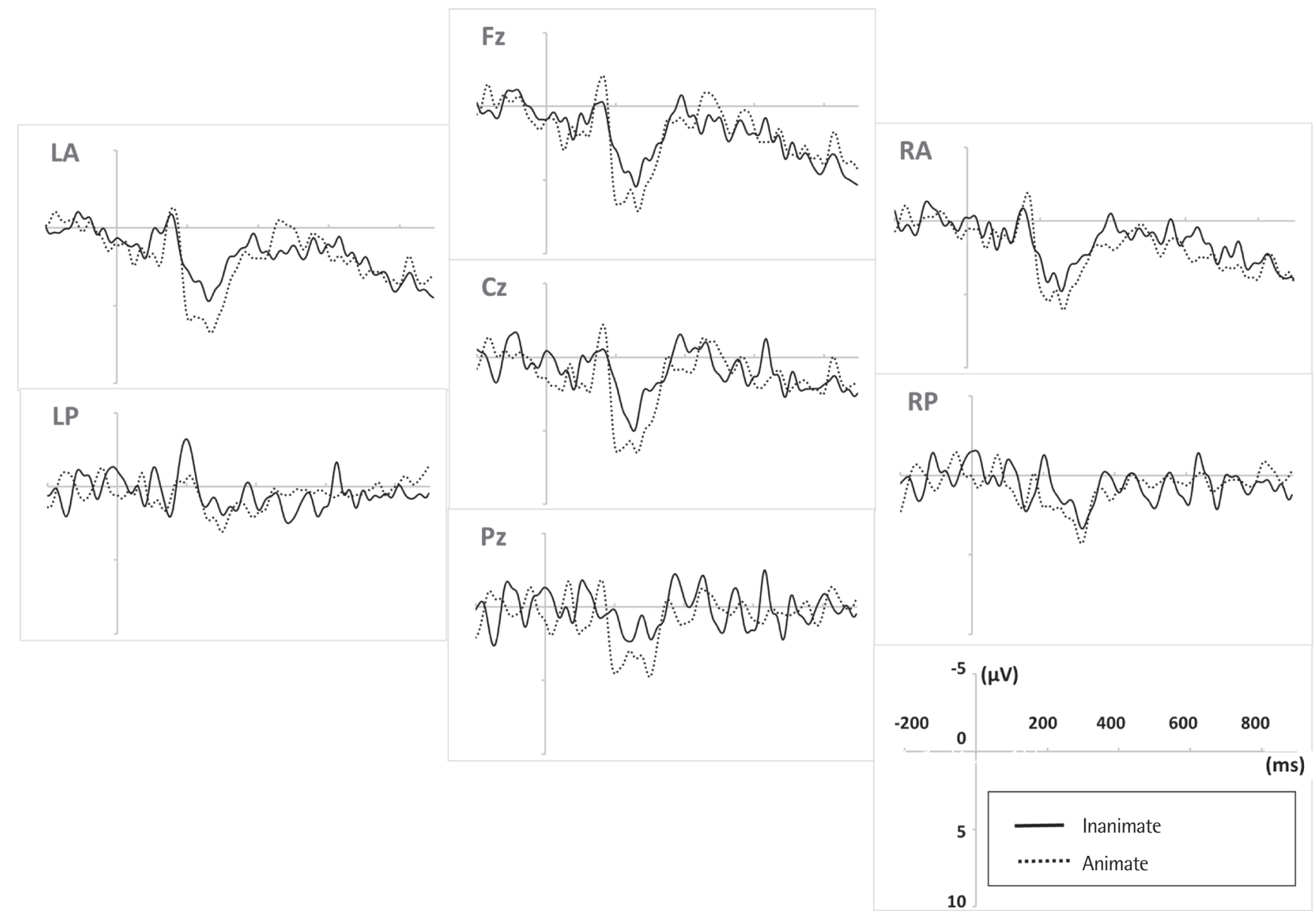

Figure 4. Grand-average waveforms for NP1 of non-canonical sentences for young adults. $L A=$ left anterior; $L P=$ left posterior; $R A=r i g h t$ anterior; $R P=$ right posterior.

stronger left-anterior negativity for animate objects. For elderly adults, there were no significant effects of animacy in any time windows. Grand-average waveforms for NP2 of canonical sentences for young and elderly adults were provided in Figures 2 and 3, respectively. The results of ANOVAs for animacy effects in each time window are shown in Table 4.

\section{Non-canonical sentences}

For young adults, a two-way repeated ANOVA (animacy $\times$ site) revealed a significant main effect for animacy $\left(F_{(1,16)}=6.423, p=.022\right)$ in the 200-400 ms time window, indicating greater negativity for inanimate objects than animate objects at the sentence initial position. A three-way repeated ANOVA (animacy $\times$ laterality $\times$ anteriority) for NP1 generated a significant main effect for animacy $\left(F_{(1,15)}=7.031, p=.018\right)$ in the $200-400 \mathrm{~ms}$ time window, indicating that inanimate objects generated a greater negativity than animate objects. No main effects or interactions of animacy approached significance in elderly adults. Grand-average waveforms for NP1 of non-canonical sentences for young and elderly adults are provided in Figures 4 and 5, respectively. The results of ANOVAs for animacy effects in each time window are shown in Table 4.

\section{CONCLUSION}

The current study investigated animacy effects as a function of word order canonicity on Korean sentence processing. Based on the animacy effects suggested in the literature, we examined whether the animacy effects were replicated in Korean sentence processing in younger and elderly adults. Behavioral results revealed that elderly adults showed significant lower performance in accuracy and reaction time for the animate object condition than for the inanimate object condition both in canonical and non-canonical 


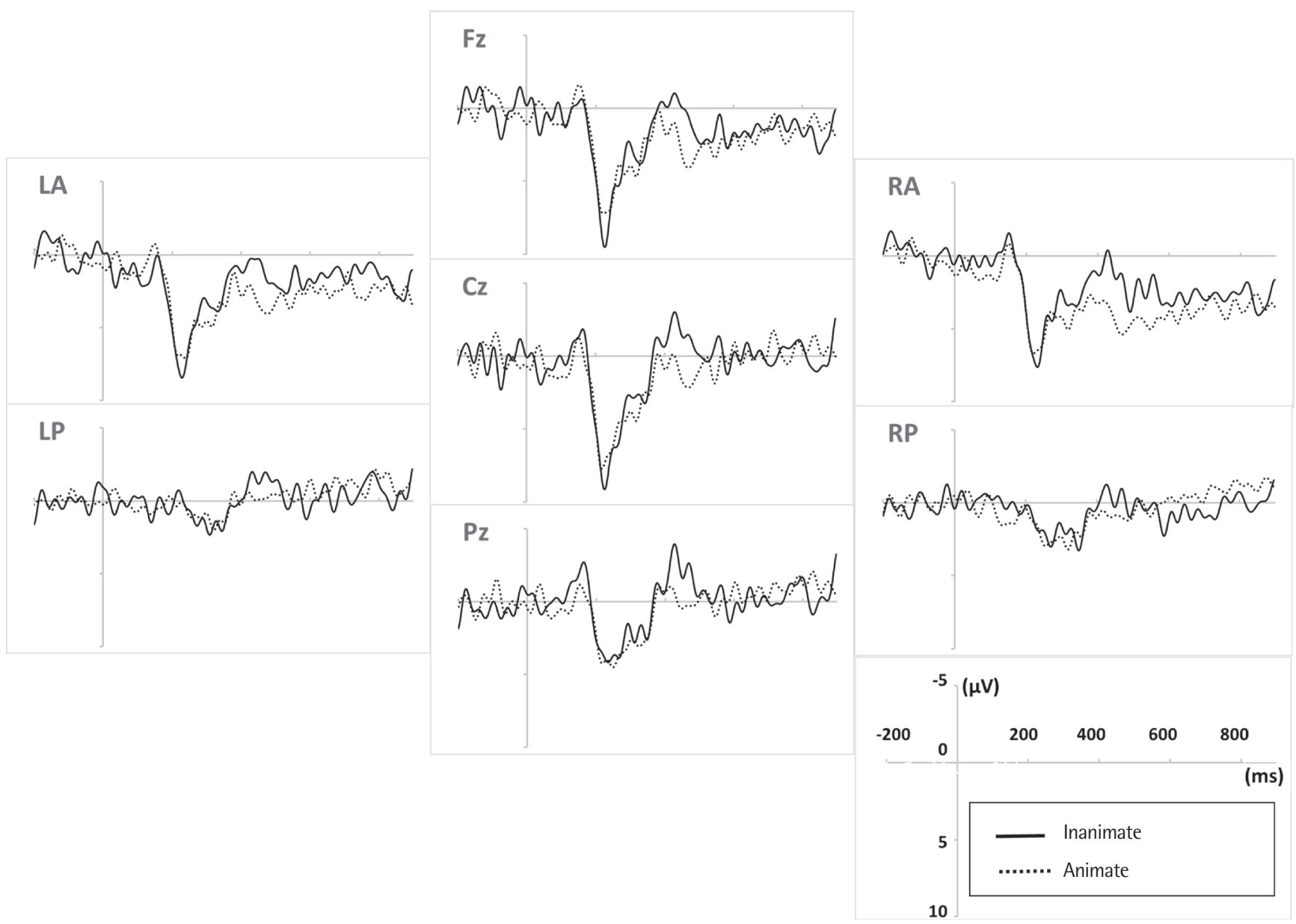

Figure 5. Grand-average waveforms for NP1 of non-canonical sentences for elderly adults. $L A=$ left anterior; $L P=$ left posterior; $R A=$ right anterior; $R P=$ right posterior.

sentences whereas younger adults showed significant slower reaction time for the animate object condition only in non-canonical sentences. These results demonstrate less efficient animacy processing during sentence comprehension in elderly adults and the ERP results could be electrophysiological evidence for these behavioral responses. ERP analyses revealed that only for younger adults, greater N400 effects were elicited for the argument nouns violating animacy hierarchy, aligned with the previous findings. Animate objects (NP2) in canonical sentences engendered greater N400 effects than inanimate objects whereas sentence initial inanimate objects (NP1) in non-canonical sentences induced greater N400 effects than animate objects. No animacy effects for any of the critical words in the analysis reached significance for the elderly group. These results demonstrate that animacy effects on sentence processing are closely related to the linear position of arguments based on animacy hierarchy and when these semantic expectancies are violated, processing costs could be raised. However, it seems that this animacy processing might be less efficient in the aging population.

Greater N400 effects for animate objects (NP2) in canonical sentences suggest that animacy effects on sentence processing should be considered in the perspective of linear ordering of sentential constituents rather than the animacy feature itself of individual entities. Considering that peak amplitude of ERPs indicates the amount of effort engaged in processing (Matzke et al., 2002), the higher amplitudes for the animate nouns at the object position than those of inanimate nouns indicate that the animate nouns at the object position require higher processing loads. In this regard, this result seems contradictory to the accessibility/salience hypothesis that animate entities are more accessible and more rapidly activated (Prat-Sala \& Branigan, 2000). Although the hypothesis has been supported at a lexical level (Bock \& Warren, 1985; Bock 
et al., 1992; McDonald et al., 1993; Park, Sung, \& Sim, 2014), it is likely to have limitations in explaining sentence level processing. Greater negativities with animate nouns than inanimate ones at the object position also indicate that animacy influences sentence processing based on animacy hierarchy. Paczynski and Kuperberg (2011) reported greater N400 effects for animate objects in plausible English sentences asserting that animacy information affects sentence processing through mapping hierarchical animacy information onto noun arguments. This implies that the human brain might prefer to process animate nouns at the sentence initial position and inanimate nouns at the second argument position based on animacy hierarchy. In the case of encountering unexpected constituents, however, additional processing costs could occur. The N400 effect reflects this increased processing cost, indicating difficulties in semantically integrating incoming sentential constituents in the context of preceding information (Kutas \& Federmeier, 2000).

The interpretation based on animacy hierarchy could be applicable to greater negativities to inanimate objects at the sentence initial position in non-canonical sentences. Greater N400 effects related to sentence initial inanimate nouns have also been reported in a couple of studies ( $\mathrm{Li}$ et al., 2015; Weckerly \& Kutas, 1999). Weckerly and Kutas (1999) suggested that higher N400 effects for sentence initial inanimate nouns might reflect reader's surprise or unexpectedness of encountering inanimate nouns at the sentence beginning since inanimate nouns are less agentive and less likely to be used as grammatical subjects in English. In Korean, this propensity could be stronger in that encountering inanimate nouns at the sentence beginning is probably less frequent than in English, given its strict compliance with animacy hierarchy (Palmer, 1994; Williamson \& Kim, 2013; Yeon, 2015). Interestingly, the current study showed that greater negativities were engendered even though the case markers informed that typical thematic role (patient) and grammatical relation (object) were assigned to the inanimate nouns. In this regard, the current results demonstrate that the N400 effect driven by animacy processing seems to be strongly modulated by linear ordering of noun arguments based on the animacy hierarchy.

The current study also aimed at examining how animacy processing would be influenced by normal aging. There were no animacy effects of significance for any of the critical words in the anal- ysis of the ERPs from the elderly participants. These results seem to be in line with previous findings. Altmann and Kemper (2006) reported that elderly adults were less sensitive to animacy information in a sentence production task, suggesting that they tended to compensate for reduced processing resources (Craik \& Byrd, 1982) by relying on environmental and perceptual cues such as the order of stimuli. While this finding showed the behavioral results of reduced animacy processing, the current study demonstrates the underlying phenomenon of animacy processing in the aging population. The less differentiated ERP patterns as a function of animacy information in elderly adults indicate that elderly adults are probably less sensitive or less efficient in animacy processing. Additionally, the current results are aligned with the previous ERP findings of individuals with lower working memory span (Nakano et al., 2010) and lower comprehension abilities (Weckerly \& Kutas, 1999) which reported attenuated N400 component. Considering reduced working memory and reading comprehension in the aging population (Grady \& Craik, 2000; Stuart-Hamilton, 2000), this is an expected result. Further research is needed concerning the underlying mechanism which could reduce the efficiency of animacy processing.

Although animacy effects on the critical noun phrases were not significant in elderly adults, visual inspection of the grand-average waveforms revealed larger N400 components to sentence initial inanimate objects than animate objects in non-canonical sentences. This implies that elderly adults might detect untypicality of animacy configuration even though the N400 effects were delayed compared to younger adults. The attenuated and delayed N400 components in the aging population have been reported in a fairly large number of ERP studies (Faustmann, Murdoch, Finnigan, \& Copland, 2007; Federmeier \& Kutas, 2005; Federmeier et al., 2002; Federmeier et al., 2003; Friederici et al., 1998; Gunter, Jackson, \& Mulder, 1995; Hamberger et al., 1995; Kutas \& Iragui, 1998). Those studies interpreted these commonly observed patterns as the result of decrement in semantic processing ability.

The current finding that animacy effects at the sentence initial position were not significant in elderly adults is somewhat surprising in that language processing at the very beginning of a sentence does not seem to require higher processing loads, compared to other positions where additional processing is required such as re- 
taining previous information and integrating it with ongoing constituents. This indicates that the ability to recognize or process untypical sentential features could be weakened in the aging population. The reduced performance of untypical sentence processing in Korean normal elderly adults was reported in a behavioral experiment. Sung (2015) found significantly worse performance in non-canonical sentence processing in elderly adults, suggesting that elderly adults are less efficient in processing untypical word order even though Korean is a relatively free word-order language.

The present study investigated age-related animacy effects as a function of word-order canonicity on Korean sentence processing. The overall results demonstrated that animacy effects on Korean sentence processing were closely related to argument configuration based on animacy hierarchy. Even though the current study presented the physiological evidence with ERPs concerning agerelated animacy effects on Korean sentence processing, further research is warranted to show a fuller picture of animacy effects on Korean sentence processing. The current study focused on animacy configuration with simple transitive sentences. Considering that animacy effects are closely associated with thematic roles and grammatical relations, it would be necessary to investigate animacy effects for nouns with different thematic or grammatical roles and examine how they are influenced by aging. Additionally, the current study manipulated animacy information with only human and inanimate nouns. Given the hierarchical perspective of animacy, it could be necessary to examine the ERP components from other types of animacy information such as animal and abstract concept for the future study. Finally, we could not include as many elderly adults in higher education as younger adults for participants due to difficulties in recruiting them. Even though the experimental stimuli in this study were simple transitive sentences with high frequency words, it is possible that efficiency in animacy processing might increase for elderly adults in higher education. Thus, performance of elderly adults in higher education needs to be examined to better elucidate aging effects on animacy processing.

\section{REFERENCES}

Altmann, L. J., \& Kemper, S. (2006). Effects of age, animacy and activation order on sentence production. Language and Cognitive Processes, 21, 322-
354.

Balota, D. A., \& Duchek, J. M. (1988). Age-related differences in lexical access, spreading activation, and simple pronunciation. Psychology and Aging, 3, 84-93.

Bock, J. K., \& Warren, R. K. (1985). Conceptual accessibility and syntactic structure in sentence formulation. Cognition, 21, 47-67.

Bock, K., Loebell, H., \& Morey, R. (1992). From conceptual roles to structural relations: bridging the syntactic cleft. Psychological Review, 99, 150-171.

Bornkessel-Schlesewsky, I., \& Schlesewsky, M. (2009). The role of prominence information in the real-time comprehension of transitive constructions: a cross-linguistic approach. Language and Linguistics Compass, 3, 19-58.

Bornkessel, I., \& Schlesewsky, M. (2006). The extended argument dependency model: a neurocognitive approach to sentence comprehension across languages. Psychological Review, 113, 787-821.

Bowles, N. L., \& Poon, L. W. (1985). Aging and retrieval of words in semantic memory. Journal of Gerontology, 40, 71-77.

Burke, D. M., \& MacKay, D. G. (1997). Memory, language, and ageing. Philosophical Transactions of the Royal Society of London B: Biological Sciences, 352, 1845-1856.

Burke, D. M., \& Peters, L. (1986). Word associations in old age: evidence for consistency in semantic encoding during adulthood. Psychology and Aging, 1, 283-291.

Chang, S. J. (1996). Korean (Vol. 4). Amsterdam: John Benjamins Publishing.

Christensen, K. J., Multhaup, K. S., Nordstrom, S. K., \& Voss, K. A. (1991). A new cognitive battery for dementia: relative severity of deficits in Alzheimer's disease. Developmental Neuropsychology, 7, 435-449.

Comrie, B. (1989). Language universals and linguistic typology: syntax and morphology. Chicago, IL: University of Chicago press.

Craik, F. I., \& Byrd, M. (1982). Aging and cognitive deficits. In F. I. M. Craik \& S. Trehub (Eds.), Aging and cognitive processes (pp. 191-211). New York, NY: Plenum.

Dahl, O., \& Fraurud, K. (1996). Animacy in grammar and discourse. In T. Fretheim \& J. K. Gundel (Eds.), Reference and referent accessibility (pp. 4764). Amsterdam: John Benjamins Publishing.

De Swart, P., Lamers, M., \& Lestrade, S. (2008). Animacy, argument structure, and argument encoding. Lingua, 118, 131-140.

Delorme, A., \& Makeig, S. (2004). EEGLAB: an open source toolbox for analysis of single-trial EEG dynamics including independent component analysis. Journal of Neuroscience Methods, 134, 9-21.

Faustmann, A., Murdoch, B. E., Finnigan, S. P., \& Copland, D. A. (2007). Ef- 
fects of advancing age on the processing of semantic anomalies in adults: evidence from event-related brain potentials. Experimental Aging Research, $33,439-460$.

Federmeier, K. D., \& Kutas, M. (2005). Aging in context: age-related changes in context use during language comprehension. Psychophysiology, 42, 133141.

Federmeier, K. D., McLennan, D. B., Ochoa, E., \& Kutas, M. (2002). The impact of semantic memory organization and sentence context information on spoken language processing by younger and older adults: an ERP study. Psychophysiology, 39, 133-146.

Federmeier, K. D., Van Petten, C., Schwartz, T. J., \& Kutas, M. (2003). Sounds, words, sentences: age-related changes across levels of language processing. Psychology and Aging, 18, 858-872.

Folli, R., \& Harley, H. (2008). Teleology and animacy in external arguments. Lingua, 118, 190-202.

Friederici, A. D., Hahne, A., \& Von Cramon, D. Y. (1998). First-pass versus second-pass parsing processes in a Wernicke's and a Broca's aphasic: electrophysiological evidence for a double dissociation. Brain and Language, 62, 311-341.

Frisch, S., \& Schlesewsky, M. (2001). The N400 reflects problems of thematic hierarchizing. NeuroReport, 12, 3391-3394.

Givón, T. (1979). On understanding grammar. New York, NY: Academic Press.

Grady, C. L., \& Craik, F. I. (2000). Changes in memory processing with age. Current Opinion in Neurobiology, 10, 224-231.

Greenhouse, S. W., \& Geisser, S. (1959). On methods in the analysis of profile data. Psychometrika, 24, 95-112.

Gunter, T. C., Jackson, J. L., \& Mulder, G. (1995). Language, memory, and aging: an electrophysiological exploration of the N400 during reading of memory-demanding sentences. Psychophysiology, 32, 215-229.

Hamberger, M. J., Friedman, D., Ritter, W., \& Rosen, J. (1995). Event-related potential and behavioral correlates of semantic processing in Alzheimer's patients and normal controls. Brain and Language, 48, 33-68.

Howard, D. V. (1983). The effects of aging and degree of association on the semantic priming of lexical decisions. Experimental Aging Research, 9, 145151.

Jasper, H. H. (1958). The ten twenty electrode system of the international federation. Electroencephalography and Clinical Neurophysiology, 10, 371375.

Hale, K. (1973). A note on subject-object inversion in Navajo. In B. B. Kachru (Ed.), Issues in linguistics: papers in honor of Henry and Renée Kahane (pp.
300-309). Urbana, IL: University of Illinois Press.

Kang, Y., Jang, S. M., \& Na, D. L (2012). Seoul Neuropsychological Screening Battery (2nd ed.). Seoul: Human Brain Research \& Consulting.

Kempen, G., \& Harbusch, K. (2004). A corpus study into word order variation in German subordinate clauses: animacy affects linearization independently of grammatical function assignment. In T. Pechmann \& C. Habel (Eds.), Multidisciplinary approaches to language production (pp. 173181). Berlin: Mouton de Gruyter.

Kuno, S. (1973). The structure of the Japanese language. Cambridge, MA: MIT Press.

Kutas, M., \& Federmeier, K. D. (2000). Electrophysiology reveals semantic memory use in language comprehension. Trends in Cognitive Sciences, 4, 463-470.

Kutas, M., \& Hillyard, S. A. (1980). Reading senseless sentences: brain potentials reflect semantic incongruity. Science, 207, 203-205.

Kutas, M., \& Iragui, V. (1998). The N400 in a semantic categorization task across 6 decades. Electroencephalography and Clinical Neurophysiology/ Evoked Potentials Section, 108, 456-471.

Lamers, M. J., \& de Swart, P. (2012). The interaction of case, word order and prominence: language production and comprehension in a cross-linguistic perspective. In M. Lamers \& P. de Swart (Eds.), Case, word order and prominence (pp. 1-15). Dordrecht: Springer.

Lee, H. (2007). Case ellipsis at the grammar/pragmatics interface: a formal analysis from a typological perspective. Journal of Pragmatics, 39, 14651481.

Li, X. Q., Zhao, H. Y., Zheng, Y. Y., \& Yang, Y. F. (2015). Two-stage interaction between word order and noun animacy during online thematic processing of sentences in Mandarin Chinese. Language, Cognition and Neuroscience, 30, 555-573.

Luck, S. J. (2014). An introduction to the event-related potential technique. Cambridge, MA: MIT press.

Matzke, M., Mai, H., Nager, W., Rüsseler, J., \& Münte, T. (2002). The costs of freedom: an ERP-study of non-canonical sentences. Clinical Neurophysiology, 113, 844-852.

McDonald, J. L., Bock, K., \& Kelly, M. H. (1993). Word and world order: semantic, phonological, and metrical determinants of serial position. Cognitive Psychology, 25, 188-230.

Minkoff, S. (2000). Animacy hierarchies and sentence processing. In A. Carnie \& E. Guilfoyle (Eds.), The syntax of verb initial language (pp. 201-212). Oxford, UK: Oxford University Press. 
Müller-Gotama, F. (1994). Grammatical relations: a cross-linguistic perspective on their syntax and semantics. Berlin: Mouton de Gruyter.

Nakano, H., Saron, C., \& Swaab, T. Y. (2010). Speech and span: working memory capacity impacts the use of animacy but not of world knowledge during spoken sentence comprehension. Journal of Cognitive Neuroscience, 22, 2886-2898.

Paczynski, M., \& Kuperberg, G. R. (2011). Electrophysiological evidence for use of the animacy hierarchy, but not thematic role assignment, during verb-argument processing. Language and Cognitive Processes, 26, 14021456.

Palmer, F. R. (1994). Grammatical roles and relations. Cambridge: Cambridge University Press.

Park, E. J., Sung, J. E., \& Sim, H. S. (2014). Age-related changes in category decision-making abilities as a function of typicality and animacy of noun exemplars. Communication Sciences \& Disorders, 19, 523-531.

Prat-Sala, M., \& Branigan, H. P. (2000). Discourse constraints on syntactic processing in language production: a cross-linguistic study in English and Spanish. Journal of Memory and Language, 42, 168-182.

Rosenbach, A. (2005). Animacy versus weight as determinants of grammatical variation in English. Language, 81, 613-644.

Scialfa, C. T., \& Margolis, R. B. (1986). Age differences in the commonality of free associations. Experimental Aging Research, 12, 95-98.

Seo, S. (1998). Word frequency in modern Korean language. Seoul: Language and Information Development Center, Yonsei University.

Song, N. S. (1987). Empathy-based affectedness and passivization. Transactions of the Philological Society, 85, 74-89.

Stuart-Hamilton, I. (2000). The psychology of aging: an introduction. London:
Jessica Kinsley Publishers.

Sung, J. E. (2015). Effects of syntactic structure on sentence comprehension ability as a function of the canonicity of word-order and its relation to working memory capacity in Korean-speaking elderly adults. Communication Sciences \& Disorders, 20, 24-33.

Taler, V., Klepousniotou, E., \& Phillips, N. A. (2009). Comprehension of lexical ambiguity in healthy aging, mild cognitive impairment, and mild Alzheimer's disease. Neuropsychologia, 47, 1332-1343.

Tyler, L. K. (1985). Real-time comprehension processes in agrammatism: a case study. Brain and Language, 26, 259-275.

Van Valin, R. D., \& LaPolla, R. J. (1997). Syntax: structure, meaning, and function. Cambridge: Cambridge University Press.

Wang, L., Schlesewsky, M., Philipp, M., \& Bornkessel-Schlesewsky, I. (2012). The role of animacy in online argument interpretation in Mandarin Chinese. In M. Lamers \& P. de Swart (Eds.), Case, word order and prominence (pp. 91-119). Dordrecht: Springer.

Weckerly, J., \& Kutas, M. (1999). An electrophysiological analysis of animacy effects in the processing of object relative sentences. Psychophysiology, 36, 559-570.

Williamson, J., \& Kim, S. Y. (2013). How animacy and agenthood influence argument order in the translation of English passive constructions to Korean. Journal of Translation Studies, 14, 263-283.

Wingfield, A. (2000). Speech perception and the comprehension of spoken language in adult aging. In D. Park \& N. Schwarz (Eds.), Cognitive aging: a primer (pp. 175-195). New York, NY: Psychology Press.

Yeon, J. (2015). Passives. In L. Brown \& J. Yeon (Eds.), The handbook of Korean linguistics (pp. 116-136). Malden, MA: Wiley-Blackwell. 


\section{국문초록}

\section{한국어 문장처리에서 나타나는 어순 전형성에 따른 생물성 효과 연구: 청년층 및 노년층의 ERP 성분 비교 분석} 오세진 · 성지은 · 심현섭

이화여자대학교 언어병리학과

배경 및 목적: 생물성은 문장의 의미역, 문법적 관계, 논항의 배열 등과 관련하여 문장처리 연구에서 중요한 주제로 다루어져 왔다. 본 연구는 사건관련전위(event-related potential, ERP)를 사용하여 타 언어권 연구에서 보고된 생물성 효과가 한국어 전형 및 비전형 어순 의 문장처리상에도 동일하게 나타나는지를 한국어를 모국어로 하는 청년층과 정상 노년층을 대상으로 알아보고자 하였다. 방법: 청년 층 16 명, 노년층 18 명으로 구성된 총 34 명의 대상자들이 문장이해과제를 수행하기 위해 실험자극을 읽는 동안 측정된 뇌파가 분석되었 다. 실험자극으로는 명사구1-부사구-명사구2-동사의 4어절로 이루어진 문장을 사용하였으며, 전형 및 비전형 어순의 문장처리 시 목적 어의 생물성 여부에 따라 다르게 나타나는 ERP의 변화를 분석하였다. 결과: 청년층의 ERP 분석 결과, 전형적 어순의 문장의 명사구2 에서는 무생물성 명사에 비해 생물성 명사에서 더 큰 N400 효과가, 비전형적 어순의 문장의 명사구1에서는 생물성 명사에 비해 무생 물성 명사에서 더 큰 N400 효과가 관찰되었다. 노년층의 ERP에서는 어떤 명사구에서도 유의한 생물성 효과가 나타나지 않았다. 논의 및 결론: 생물성 위계에 따른 논항 배열의 선호로 인한 생물성 효과가 청년층의 문장처리에서는 나타났으나, 노년층에서는 나타나지 않 았다. 이는 인지적 노화 과정에서 나타나는 생물성 정보처리 능력의 약화에 기인하는 결과로 추측된다.

핵심어: ERP, N400, 생물성, 어순 전형성, 노화, 문장처리

본 연구는 2016년 대한민국 교육부와 한국연구재단의 지원을 받아수행된 연구임(NRF-2016S1A5B6913884). 